\title{
Disability relating to instrumental activities of daily living in the elderly with rheumatic diseases
}

\author{
Priscila Maria Stolses Bergamo Francisco' \\ Priscila de Paula Marques' \\ Flávia Silva Arbex Borim? \\ Sarina Francescato Torres' \\ Anita Liberalesso Neri'
}

\section{Abstract}

Objective: to characterize the sociodemographic profile of elderly persons with arthritis/ rheumatism in relation to gender, as well as to estimate the prevalence and factors associated with functional disability for the performance of instrumental activities of daily living (IADL). Method: a cross-sectional population-based study with a sample of 1,136 elderly persons ( $\geq 65$ years old) from seven Brazilian municipal regions was carried out. Functional capacity was assessed by the self-reports of the elderly in terms of the performance of IADL, using the Lawton Scale. Differences between the genders, according to sociodemographic variables, were verified by the chi-squared test $(p<0.05)$. The prevalence of inability to perform IADL was calculated and the independent associations were verified through multiple logistic regression. Results: the mean age was 72.4 years, $79.1 \%$ of the sample were women, and $45.9 \%$ of the elderly with arthritis/rheumatism were dependent for the performance of IADL. Differences were observed between the genders in relation to age, marital status, income and household arrangements $(p<0.05)$. A higher prevalence of disability was observed among older elderly persons, those with no schooling and lower incomes, who lived in multigenerational households and who were frail. In the evaluation of the performance of specific activities, elderly persons with arthritis/rheumatism had greater difficulty taking medication (OR: 1,90; CI 95\%: 1.19 - 3.06), after adjusting for gender and age. Conclusion: associations were found between functional disability and sociodemographic variables and frailty. Independence in daily activities such as those evaluated in this study is one of the primary conditions for the well-being of the elderly, even in conditions of frailty or chronic diseases.

\footnotetext{
Universidade Estadual de Campinas, Faculdade de Ciências Médicas, Programa de pós-graduação em Gerontologia. Campinas, São Paulo, Brasil.

Correspondence

Priscila Maria Stolses Bergamo Francisco

primaria@fcm.unicamp.br
}

Keywords: Elderly. Aging. Activities of Daily Living. Rheumatic Diseases. CrossSectional Studies. 


\section{INTRODUCTION}

The ageing of the Brazilian population in recent decades, together with changes in epidemiological patterns and structure and social and family behavior, have resulted in new needs, including a restructuring of health and social policies. ${ }^{1}$. The ageing process involves a greater occurrence of chronic diseases ${ }^{2,3}$ and a higher frequency of functional disability, which is characterized by restrictions in the physical and mental skills required for an individual to maintain their independence and autonomy in the performance of basic activities of daily living as well as activities of greater complexity ${ }^{4}$

The performance of activities of daily living depends on the general health status and motor functions of the individual. These are most impaired in situations of acute adverse health conditions, morbidities, cognitive decline and the occurrence of multiple chronic conditions, which are common among the elderly ${ }^{5}$. Rheumatic diseases have a greater impact on years of life with disability ${ }^{6}$.

Rheumatic diseases are defined as health problems that affect the connective tissues, causing harm to the skin, heart, joint structures and periarticular structures. There are approximately 100 of such diseases, which are usually chronic and involve pain, joint stiffness and physical disability. Moreover, studies have demonstrated a high prevalence rate of rheumatic diseases in the elderly population ${ }^{2,7,8}$. Data from the 2008 Brazilian National Household Survey demonstrate prevalence rates of $21.3 \%, 26.3 \%$ and $31.5 \%$ among individuals aged 60 to 69 years, 70 to 79 years and 80 years or older, respectively ${ }^{2}$. Factors such as the female gender, advanced age, a sedentary lifestyle, excess weight, low socioeconomic status and smoking, among others, are associated with the development of rheumatic diseases ${ }^{9,10,11}$

There are few population-based studies in Brazilian scientific literature that evaluate functional capacity in elderly persons with specific chronic diseases. Therefore, the aims of the present study were to characterize the socio-demographic profile of elderly persons with arthritis and rheumatism, stratified by gender, estimate the prevalence of functional disability in the performance of instrumental activities of daily living, determine the associated factors and compare levels of dependence for each instrumental activity of daily living among elderly persons with and without rheumatic diseases.

\section{METHODS}

The present study was conducted with data from a study on frailty among the elderly conducted in 2008/2009 (FIBRA network - Network of Studies on Frailty among the Brazilian Elderly). A populationbased cross-sectional study was conducted with a sample of 3478 older adults ( $\geq 65$ years) recruited from the community, of whom 1136 reported having a medical diagnosis of arthritic or rheumatism. The participants were residents of urban areas in six cities: Campinas in the state of São Paulo, Belém in the state of Pará, Parnaíba in the state of Piauí, Campinas Grande in the state of Paraíba, Poços de Caldas in the state of Minas Gerais, Ivoti in the state of Rio Grande do Sul and the subdistrict of Ermelino Matarazzo in the city of São Paulo, which were selected by convenience.

In each location, a number of representative urban census sectors were drawn by simple lottery. For each sector, the population of men and women in three age groups (65 to 69 years, 70 to 79 years and 80 years or older) sufficient to represent the respective realities was estimated.

The census sectors were visited and the residents were contacted in their homes by a team of trained interviewers (university students, community health agents and volunteers from religious organizations) ${ }^{12}$ until the desired samples were obtained, plus 50\% to compensate for possible dropouts. The interviews were held a posteriori at a previously announced public location. The individuals were provided with information on the objectives, content, conditions and ethical aspects of the study. Those who agreed to participate received a card with the date, time and location of the interview.

In this phase, elderly persons with deficits in terms of memory, attention, spatial/temporal orientation and communication suggestive of cognitive deficit (observed by the recruiting team) were excluded. At the criteria of the recruiters, individuals with severe mobility, speech or affectivity impairment associated with advanced Parkinson's disease, those with the permanent or temporary inability to walk 
(except those who used a gait-assistance device), those with localized loss of strength and aphasia stemming from a stroke, those with severe hearing or visual impairment and those in the terminal stage were excluded ${ }^{12}$

The individuals who attended the scheduled locations again received clarifications regarding the objectives and conditions of the study and signed a free and informed consent form.

Data were collected using a previously tested questionnaire administered by trained interviewers. At the beginning of the interview, all individuals were submitted to the Mini Mental State Examination ${ }^{13,14}$, the score of which was used to exclude individuals with cognitive impairment suggestive of dementia (cutoff points: 17 for illiterate individuals, 22 for those with one to four years of schooling, 24 for those with five to eight years of schooling and 26 for those with nine or more years of schooling). Based on this criterion, 883 individuals were excluded, leaving a sample of 2593 older adults who responded to the items of interest for the present study.

Individuals with rheumatic disease were identified based on the answer to the following question: "Has a doctor told you that you have arthritis or rheumatism?" (yes or no). Functional capacity was evaluated based on self-reports regarding the amount of assistance (none, partial or complete) needed for the performance of instrumental activities of daily living (IADLs) (eight items on the Lawton Scale) ${ }^{15}$. Individuals who reported requiring partial or complete assistance for one or more activities were classified as dependent.

The following were selected as the independent variables for the analysis of factors associated with functional capacity:

Socio-demographic characteristics: gender (male or female), age group (65 to $69 ; 70$ to $74 ; 75$ to 79 ; $\geq$ 80 years), marital status (married, single/divorced/ widowed), schooling ( 0,1 to $4, \geq 5$ years of study), household income based on the Brazilian monthly minimum wage $(\mathrm{MW})$ at the time of the study $(<$ one MW; one to three times the MW; more than three times the MW) and living arrangement (lives alone, lives only with spouse, lives with descendents, spouse/descendents/other relatives and external/ mixed arrangement).
Care expectations: determined based on the answer to the following question: "Ifyou need help doing any of these activities (IADLs/BADLs), do you have anyone you can rely on?" Based on the possible responses (alone, spouse only, spouse and son/daughter, son/daughter and grandchildren, other relatives/friends/health professional; this variable was dichotomized as "no" (alone) or "yes" (other answers).

Perception of self-care: evaluated on a scale with five degrees of intensity (excellent, good, fair, poor and very poor) based on the answer to the following question: "How do you rate the care that you dedicate to your health?"

Indicators of frailty: the five criteria proposed by Fried et al. (2001) were considered ${ }^{16}$ (unintentional weight loss in previous year, fatigue, weakness, slowness and low level of physical activity). Individuals with three or more components were classified as frail, those with one or two components were classified as pre-frail and those with no components were classified as non-frail.

Self-rated health: determined based on the answer to the following question: "In general, how would you rate your health?" The responses were categorized as excellent/good and fair/poor/very poor.

The socio-demographic distribution of the older adults with arthritis or rheumatism was determined based on relative frequencies stratified by gender, and the differences between the groups were verified. The comparisons were performed using the chi-squared test with a $5 \%$ significance level. The prevalence of disability regarding the performance of specific IADLs was estimated according to the presence/ absence of arthritis or rheumatism. Odds ratios (OR) adjusted for gender and age and respective 95\% confidence intervals (CI) were also calculated.

Crude and adjusted (gender and age) ORs and respective CIs of $95 \%$ were estimated to identify factors associated with functional capacity in the performance of IADLs in elderly persons with arthritis or rheumatism. Variables with a $p$-value $<0.20$ in the simple analysis were incorporated into the multiple regression model. The backward selection method was employed and only those variables with a $p$-value $<0.05$ remained in the final model. The Stata 14.0 program was used or all statistical analyses. 
This study was approved by the Human Research Ethics Committee of the School of Medical Science of the Universidade Estadual de Campinas (certificate number: 208/2007, May 22 nd 2007 ; certificate number: 0151.1.146.000-07) and again on December $10^{\text {th }}, 2014$ (certificate number: 39547014.0.1001.5404).

\section{RESULTS}

Among the 1136 elderly persons who reported having a medical diagnosis of arthritis or rheumatism, $79.1 \%$ were women, the mean age was 72.4 years (standard deviation: 5.6 years) and the maximum age was 96 years. A total of $45.9 \%$ (95\% CI: 41.9 to 49.8\%) of the individuals with arthritis or rheumatism were dependent in the performance of IADLs.

Table 1 displays the socio-demographic characteristics of the elderly persons with arthritis or rheumatism stratified by gender. A total of $28.7 \%$ of the men and $31.5 \%$ of the women were $\geq 75$ years of age at the time of the interview and $63.0 \%$ of the women were single/divorced/widowed. The majority had $\leq$ four years of schooling and a household income $\leq$ three times MW. Regarding living arrangements, $6.4 \%$ of the men and $16.7 \%$ of the women lived alone $(p<0.001)$.

Table 2 displays the factors associated with functional disability in the performance of IADLs among the elderly persons with arthritis or rheumatism. The prevalence of functional disability was higher among those with no schooling, those with an income less than one MW in comparison to those with an income $\geq 3 \mathrm{MW}$ at the time of the interview, those who lived with a son/daughter or a spouse and son/daughter or other living arrangements and those classified as frail or pre-frail. Regarding self-rated health, $54.0 \%$ of the elderly persons with arthritis or rheumatism considered their health to be fair, poor or very poor and the prevalence of functional disability was higher in this subgroup $(\mathrm{OR}=1.67$; 95\% CI: 1.18 to 2.36$)$.

Table 1. Socio-demographic characteristics of elderly persons with arthritis or rheumatism; FIBRA study, 2008-2009.

\begin{tabular}{|c|c|c|c|c|c|c|c|}
\hline \multirow[t]{2}{*}{ Variables } & \multicolumn{2}{|c|}{ Total } & \multicolumn{2}{|c|}{ Men } & \multicolumn{2}{|c|}{ Women } & \multirow{2}{*}{$p$} \\
\hline & $\mathrm{n}$ & $\%$ & $\mathrm{n}$ & $\%$ & $\mathrm{n}$ & $\%$ & \\
\hline Age group & & & & & & & 0.009 \\
\hline 65-69 years & 421 & 37.1 & 84 & 35.4 & 337 & 37.5 & \\
\hline $70-74$ years & 364 & 32.0 & 85 & 35.9 & 279 & 31.0 & \\
\hline $75-79$ years & 219 & 19.3 & 31 & 13.1 & 188 & 20.9 & \\
\hline 80 years or more & 132 & 11.6 & 37 & 15.6 & 95 & 10.6 & \\
\hline Marital status & & & & & & & $<0.001$ \\
\hline Married/civil union & 511 & 45.0 & 179 & 75.5 & 332 & 37.0 & \\
\hline Single/divorced/widowed & 624 & 55.0 & 58 & 24.5 & 566 & 63.0 & \\
\hline Schooling & & & & & & & 0.477 \\
\hline None & 277 & 20.0 & 46 & 19.4 & 181 & 20.2 & \\
\hline $1-4$ years & 552 & 48.6 & 109 & 46.0 & 443 & 49.3 & \\
\hline$\geq 5$ years & 356 & 31.4 & 82 & 34.6 & 274 & 30.5 & \\
\hline Monthly family income & & & & & & & 0.017 \\
\hline$<1 \mathrm{MW}^{*}$ & 252 & 22.2 & 43 & 18.2 & 209 & 23.3 & \\
\hline 1 to $>3$ times MW & 498 & 44.0 & 97 & 41.1 & 401 & 44.7 & \\
\hline 3 to $<5$ times MW & 224 & 19.8 & 49 & 20.8 & 175 & 19.5 & \\
\hline$\geq 5$ times MW & 159 & 14.0 & 47 & 19.9 & 112 & 12.5 & \\
\hline Living arrangement & & & & & & & $<0.001$ \\
\hline Alone & 164 & 14.6 & 15 & 6.4 & 149 & 16.7 & \\
\hline With spouse & 219 & 19.4 & 75 & 31.9 & 144 & 16.2 & \\
\hline With offspring & 320 & 28.4 & 20 & 8.5 & 300 & 33.7 & \\
\hline With spouse and offspring & 253 & 22.5 & 100 & 42.5 & 153 & 17.2 & \\
\hline Other relatives and non-relatives/others & 170 & 15.1 & 25 & 10.6 & 145 & 16.3 & \\
\hline
\end{tabular}

Source: FIBRA 2008-2009.

*Minimum wage. 
Table 2. Prevalence of functional disability in instrumental activities of daily living and associated factors in elderly persons with arthritis/rheumatism; FIBRA study, 2008-2009.

\begin{tabular}{|c|c|c|c|c|c|}
\hline Variables & $\begin{array}{l}\text { Functional } \\
\text { disability }\end{array}$ & $\mathrm{OR}_{\text {crude }}$ & $95 \% \mathrm{CI}$ & $\mathrm{OR}_{\text {Adjusted }}$ & $95 \% \mathrm{CI}$ \\
\hline \multicolumn{6}{|l|}{ Gender } \\
\hline Male & 41.5 & 1 & & 1 & \\
\hline Female & 47.1 & 1.25 & $0.85-1.85$ & 1.30 & $0.88-1.93$ \\
\hline \multicolumn{6}{|l|}{ Age group } \\
\hline $65-69$ years & 37.4 & 1 & & 1 & \\
\hline $70-74$ years & 47.4 & 1.50 & $1.02-2.22$ & 1.53 & $1.03-2.26$ \\
\hline $75-79$ years & 50.0 & 1.67 & $1.07-2.61$ & 1.65 & $1.06-2.58$ \\
\hline$\geq 80$ years & 62.7 & 2.81 & $1.60-4.93$ & 2.89 & $1.64-5.10$ \\
\hline \multicolumn{6}{|l|}{ Marital status } \\
\hline Married/civil union & 42.1 & 1 & & 1 & \\
\hline Single/divorced/widowed & 48.7 & 1.30 & $0.94-1.80$ & 1.10 & $0.77-1.56$ \\
\hline \multicolumn{6}{|l|}{ Schooling } \\
\hline None & 67.5 & 1 & & 1 & \\
\hline 1 - 4 years & 43.2 & 0.37 & $0.23-0.57$ & 0.38 & $0.24-0.59$ \\
\hline$\geq 5$ years & 36.7 & 0.28 & $0.17-0.45$ & 0.31 & $0.19-0.50$ \\
\hline
\end{tabular}

Monthly family income

\begin{tabular}{|c|c|c|c|c|c|}
\hline$<1 \mathrm{MW}^{*}$ & 50.3 & 1 & & 1 & \\
\hline 1 to $<3$ times MW & 51.4 & 1.04 & $0.70-1.56$ & 1.04 & $0.69-1.57$ \\
\hline$\geq 3$ times MW & 34.2 & 0.51 & $0.33-0.80$ & 0.53 & $0.33-0.83$ \\
\hline
\end{tabular}

Living arrangement

Alone
With spouse
With offspring
With spouse and offspring/others

34.6

$\begin{array}{llll}35.0 & 1.02 & 0.55-1.89 & 1.24\end{array}$

$\begin{array}{llll}53.6 & 2.18 & 1.26-3.78 & 2.33\end{array}$

$.65-2.36$

53.6

1.74

$1.03-2.96 \quad 2.03$

$1.33-4.09$

Care expectations

No
Yes

52.1

Perception of self-care

Very good/good

45.9

1

$1.18-3.52$

Fair/poor/very poor

$45.3 \quad 1$

0.78

$0.43-1.41$

1

Frailty

Non-frail

46.7

1

$1.06 \quad 0.77-1.45$

1.09

$0.79-1.51$

Pre-frail

36.1

1

64.3

1.77

$1.25-2.50$

1

Frail

64.3

3.18

$1.73-5.84$

2.94

$1.20-2.41$

Number of chronic diseases

None or one

43.0

1

Two or more

47.9

1.22

$0.88-1.69$

1.19

$0.85-1.65$

Self-rated health

Very good/good

1

54.0

1.63

$1.16-2.29$

1

Fair/poor/very poor

Source: FIBRA 2008-2009.

*Minimum wage. 
In the multiple regression analysis, functional disability was more frequent among individuals with lower schooling and income, those who lived with a spouse/descendent or who had other living arrangements and those with some degree of frailty (Table 3).
Table 4 lists the IADLs on which the elderly persons were dependent stratified by the presence/ absence of arthritis or rheumatism. A significant difference between groups was found for taking prescription medications (OR: 1.90; 95\% CI: 1.19 to 3.06) after the adjustments for gender and age.

Table 3. Multiple regression analysis for functional disability in instrumental activities of daily living among elderly persons with arthritis/rheumatism; FIBRA study, 2008-2009.

\begin{tabular}{|c|c|c|c|}
\hline Variables & $\mathrm{OR}_{\text {adjusted }}(95 \% \mathrm{CI})$ & $p$-value & Standard error \\
\hline \multicolumn{4}{|l|}{ Age group } \\
\hline 65-69 years & 1 & & \\
\hline $70-74$ years & $1.52(1.01-2.29)$ & 0.048 & 0.319 \\
\hline $75-79$ years & $1.35(0.84-2.17)$ & 0.219 & 0.327 \\
\hline$\geq 80$ years & $2.50(1.37-4.55)$ & 0.003 & 0.765 \\
\hline \multicolumn{4}{|l|}{ Schooling } \\
\hline None & 1 & & \\
\hline $1-4$ years & $0.42(0.26-0.67)$ & $<0.001$ & 0.100 \\
\hline$\geq 5$ years & $0.37(0.22-0.62)$ & $<0.001$ & 0.097 \\
\hline \multicolumn{4}{|l|}{ Monthly family income } \\
\hline$<1 \mathrm{MW}^{*}$ & 1 & & \\
\hline 1 to $<3$ times MW & $0.91(0.59-1.42)$ & 0.693 & 0.206 \\
\hline$\geq 3$ times MW & $0.59(0.36-0.96)$ & 0.036 & 0.148 \\
\hline \multicolumn{4}{|l|}{ Living arrangement } \\
\hline Alone & 1 & & \\
\hline With spouse & $1.31(0.67-2.56)$ & 0.425 & 0.448 \\
\hline With descendants & $2.47(1.38-4.41)$ & 0.002 & 0.732 \\
\hline With spouse and descendants/others & $2.24(1.26-3.95)$ & 0.006 & 0.650 \\
\hline \multicolumn{4}{|l|}{ Frailty } \\
\hline Non-frail & 1 & & \\
\hline Pre-frail & $1.58(1.10-2.28)$ & 0.014 & 0.294 \\
\hline Frail & $2.49(1.30-4.76)$ & 0.006 & 0.824 \\
\hline
\end{tabular}

Source: FIBRA 2008-2009.

*Minimum wage.

Table 4. Dependence in instrumental activities of daily living among elderly persons according to the presence/ absence of arthritis or rheumatism; FIBRA study, 2008-2009.

\begin{tabular}{|c|c|c|c|c|c|c|c|}
\hline \multirow{3}{*}{ Instrumental activities } & \multicolumn{7}{|c|}{ Arthritis or rheumatism } \\
\hline & \multicolumn{2}{|c|}{ Yes } & \multicolumn{2}{|l|}{ No } & \multirow[t]{2}{*}{$p$} & \multirow{2}{*}{$\mathrm{OR}_{\text {adjusted }}$} & \multirow[t]{2}{*}{$95 \%$ CI } \\
\hline & $\mathrm{n}$ & $\%$ & $\mathrm{n}$ & $\%$ & & & \\
\hline Using telephone & 99 & 45.6 & 118 & 54.4 & 0.979 & 0.95 & $0.70-1.28$ \\
\hline Using means of transportation & 74 & 45.7 & 88 & 54.3 & 0.941 & 0.80 & $0.57-1.13$ \\
\hline Shopping for groceries & 122 & 52.4 & 111 & 47.6 & 0.019 & 1.13 & $0.84-1.52$ \\
\hline Housework & 149 & 48.4 & 159 & 51.6 & 0.244 & 1.09 & $0.83-1.42$ \\
\hline Preparing meals & 68 & 38.9 & 107 & 61.1 & 0.061 & 1.15 & $0.80-1.63$ \\
\hline Managing money & 90 & 49.5 & 92 & 55.5 & 0.244 & 1.02 & $0.74-1.42$ \\
\hline Taking medications & 50 & 61.0 & 32 & 39.0 & 0.004 & 1.90 & $1.19-3.06$ \\
\hline
\end{tabular}

Source: FIBRA 2008-2009 


\section{DISCUSSION}

Inequalities were found in the prevalence of functional disability in the performance of IADLs among elderly persons with rheumatic diseases. There was a greater rate of disability among those with a poorer socioeconomic status and those classified with some degree of frailty (one or more of the five frailty components). No significant associations were found between functional disability and gender, marital status, care expectations, perception of selfcare or morbidities.

Among individuals aged 70 years or older, the disease is more prevalent in women who live alone. Elderly women are more numerous than elderly men, and this difference increases over the years ${ }^{17}$. The predominance of women at more advanced ages is a result of many factors, including the tendency among women to take better care of themselves and seek medical and/or social care ${ }^{17}$ Gender differences in the health of elderly persons reveal that elderly women suffer a greater burden of functional decline ${ }^{18}$. Especially with regard to rheumatic diseases, studies report higher prevalence rates of osteoarthritis and rheumatoid arthritis in women ${ }^{8,11}$

The prevalence of disability regarding the performance of IADLs among elderly persons with arthritis or rheumatism was $46.0 \%$ in the present study, demonstrating that nearly half of these individuals had restricted independence in terms of daily activities related to mobility or housework ${ }^{4}$. Literature offers little data on the prevalence of functional disability in the performance of IADLs in this subgroup of elderly persons. Chronic inflammatory joint diseases cause constant, prolonged pain that exerts a considerable impact on the lives of affected individuals, rendering them unable to perform day to day tasks ${ }^{19}$. A previous study has identified an association between limited mobility and functional disability in patients with rheumatic disease ${ }^{20}$

In the present study, functional disability was more prevalent among individuals with lower schooling and income as well as those who lived with a spouse and offspring or had other living arrangements. Non-communicable chronic diseases generally have a greater effect on populations with low schooling and income ${ }^{2,21}$ who are more vulnerable and more exposed to risks and have less access to healthcare services ${ }^{2,22,23}$

A previous study involving individuals with rheumatic diseases found an association between low socioeconomic status and a greater prevalence of functional disability ${ }^{24}$ The successive accumulation of social needs throughout the life cycle of the individual, which is reflected in multi-generational living arrangements, exerts a negative influence on adherence to practices of health promotion and disease prevention, with impacts on disease control and functional independence during the ageing process. Inequalities regarding the distribution of income and a low level of economic protection for elderly persons make inequality more severe in this segment of the population.

Frailty is considered a clinical syndrome associated with normal physiological ageing and is described as a clinical state of increased vulnerability expressed as reductions in both compensatory responses and the maintenance of homeostasis in the presence of stressors ${ }^{16}$ The greater prevalence of disability regarding activities of daily living among elderly persons classified as pre-frail or frail in the present study may be related to the high prevalence of pain in the population with arthritis ${ }^{25,26}$ as well as the frailty syndrome, which predisposes elderly persons to a reduction in muscle mass and a chronic inflammatory state ${ }^{16}$.

Differences in age and gender composition were considered in the analysis of functional disability with regard to each specific instrumental activity, as functional decline is a progressive process ${ }^{27}$ associated with both an increase in disease burden and considerable health differences between ageing men and women. After adjustments for age and gender, a greater prevalence of disability was found among the elderly persons with arthritis or rheumatism in terms of taking prescription medications. This declared difficulty and the need for assistance regarding the use of medications should be considered by both health professionals and family members so that they can assist these elderly persons in adhering to medical treatment. The low level of schooling of elderly persons should also be taken into consideration when providing medical counseling. 
Limitations of the present study include the use of self-reported information and the impossibility of establishing causal relationships due to its crosssectional design. Irrespective of the health condition evaluated, older populations have a greater likelihood of developing diseases and disabilities than those in locations where the elderly are concentrated in a younger age group ${ }^{27}$ However, the present study considered elderly persons residing in the urban areas of seven cities located in the southern, southeastern, northern and northeastern regions of Brazil, with different demographic profiles. Studies addressing basic and advanced activities of daily living can help clarify the impact of rheumatic diseases. Moreover, qualitative approaches can contribute to a better understanding of the difficulties relating to the use of medications.

Independence in the performance of activities of daily living, which are evaluated in the present study, is one of the key conditions for the well-being of the elderly, even when the individual is frail or suffers from a chronic disease. An individual and social approach is required to create better living conditions in old age, characterized by autonomy and quality of life, as well as interventions for healthy aging, with accessible services focusing on the most vulnerable populations ${ }^{28}$.

\section{CONCLUSION}

The present study found differences in the prevalence of elderly persons with arthritis or rheumatism based on gender and sociodemographic profile. Associations between functional disability in instrumental activities of daily living and sociodemographic variables and frailty were also identified. When dependence in activities of daily living based on presence of the disease was assessed, there was a difference between the groups in terms of use of medication.

\section{REFERENCES}

1. Organização Mundial de Saúde. Relatório mundial de envelhecimento e saúde. Geneba: OMS; 2015.

2. Barros MBA, Francisco PMSB, Zanchetta LM, Cesar CLG. Tendências das desigualdades sociais e demográficas na prevalência de doenças crônicas no Brasil, PNAD: 2003- 2008. Ciênc Saúde Colet. 2011;16(9):3755-68.

3. Instituto Brasileiro de Geografia e Estatística. Pesquisa Nacional de Saúde, 2013 : acesso e utilização dos serviços de saúde, acidentes e violências: Brasil, grandes regiões e unidades da federação. Rio de Janeiro: IBGE; 2015.

4. Freitas RS, Fernandes MH, Coqueiro RDS, et al. Capacidade funcional e fatores associados em idosos: estudo populacional. Acta Paul Enferm. 2012;25(6):933-9.

5. Costa Filho AM. Contribuiçăo das doenças crônicas na prevalência da incapacidade para as atividades básicas (ABVD) e instrumentais (AIVD) de vida diária entre idoso brasileiros: Pesquisa Nacional de Saúde (2013) [Dissertação na Internet]. Belo Horizonte: FIOCRUZ; 2016 [acesso em 18 nov. 2018]. Disponível em: http:// www.arca.fiocruz.br/handle/icict/17921

6. Campolina AG, Adami F, Santos JLF, Lebrão ML. A transição de saúde e as mudanças na expectativa de vida saudável da população idosa: possíveis impactos da prevenção de doenças crônicas. Cad Saúde Pública. 2013;29(6):1217-29.

7. Gafvels C, Hagerstrom M, Nordmark B, Wandell P. What predicts negative effects of rheumatoid arthritis?: follow-up two years after diagnosis. Springer Plus. 2014;3(118):1-10.

8. Torres SF. Doenças reumáticas em idosos da comunidade e variáveis associadas: dados do Estudo Fibra [Dissertação]. Campinas: Universidade Estadual de Campinas, Faculdade de Ciências Médicas; 2016.

9. Blay SL, Fillenbaum GG, Andreoli SB, Gastal FL. Prevalence and concomitants of arthritis in the elderly in Rio Grande do Sul, Brazil. PLoS One. 2012;7(9):1-7.

10. Brown EM, Garneau KL, Tsao H, Solomon DH. DMARD non-use in low-income, elderly rheumatoid arthritis patients: results of 86 structured interviews. Arthritis Res Ther. 2014;16(1):30-7. 
11. Costa JO, Almeida AM, Guerra Junior AA, Cherchiglia ML, Andrade EIG, Acurcio FdA. Treatment of rheumatoid arthritis in the Brazilian Unified National Health System: expenditures on infliximab compared to synthetic disease-modifying anti-rheumatic drugs, 2003-2006. Cad Saúde Pública. 2014;30(2):283-95.

12. Neri AL, Yassuda MS, Araújo LF, Eulálio MC, Cabral BE, Siqueira MEC, et al. Metodologia e perfil sociodemográfico, cognitivo e de fragilidade de idosos comunitários de sete cidades brasileiras: Estudo FIBRA. Cad SaúdePública. 2013;29(4):778-92.

13. Melo DM, Barbosa AJG. Use of the Mini-Mental State Examination in research on the elderly in Brazil: a systematic review. Ciênc Saúde Colet [Internet]. 2015 [acesso em 20 nov. 2017];20(12):3865-76. Disponível em: http://www.scielo.br/scielo.php?script=sci_artte xt\&pid=S1413-81232015001203865

14. Brucki SMD, NitrinI R, Caramelli P, Bertolucci PHF, Okamoto IH. Sugestões para o uso Mini-Exame do Estado Mental no Brasil. Arq Neuropsiquiatr. 2003;61(3B):777-81

15. Lawton MP, Brody EM. Assessment of older people: self-maintaining and instrumental activities of daily living. Gerontologist. 1969;9(3):179-86.

16. Fried L, Tangen C, Walston J, Newman A, Hirsch C, Gottdiener J, et al. Frailty in older adults: evidence for a phenotype. J Gerontol Ser A Biol Sci Med Sci. 2001;56(3):146-56.

17. Santos DV, Moreira MAA, Cerveny C. Velhice: considerações sobre o envelhecimento: imagens no espelho. Nova Perspect Sist. 2014;23(48):80-94.

18. Campos ACV, Almeida MHM, Campos GV, Bogutchi TF. Prevalência de incapacidade funcional por gênero em idosos brasileiros: uma revisão sistemática com metanálise. Rev Bras Geriatr Gerontol. 2016;19(3):545-59.

19. Santana FS, Nascimento DC, Freitas JPM, Miranda RF, Muniz LF, Santos Neto L, Mota LMH, et al. Avaliação da capacidade funcional em pacientes com artrite reumatoide: implicações para a recomendação de exercícios físicos. Rev Bras Reumatol. 2014;54(5):378-85.
20. Marques WV, Cruz VA, Rego J, Silva NA. Influência das comorbidades na capacidade funcional de pacientes com artrite reumatoide. Rev Bras Reumatol. 2016;56(1):14-21.

21. World Health Organization. Health statistics and information systems: estimates for 2000-2012 [Internet]. Geneva: WHO; 2013? [acesso em 03 nov. 2014]. Disponível em: http://www.who.int/healthinfo/ global_burden_disease/estimates/en/index1.html

22. Malta DC, Bernal RTI, Lima MG, Araújo SSC, Silva MMA, Freitas MIF, et al. Doenças crônicas não transmissíveis e a utilização de serviços de saúde: análise da Pesquisa Nacional de Saúde no Brasil. Rev Saúde Pública. 2017;51 Supl 1:1-4.

23. Gavasso WC, Beltrame V. Capacidade funcional e morbidades referidas: uma análise comparativa em idosos. Rev Bras Geriatr Gerontol. 2017;20(3):399-409.

24. Callhoff J, Luque Ramos A, Zink A, Hoffmann F, Albrecht K. The Association of low income with functional status and disease burden in German patients with rheumatoid arthritis: results of a crosssectional questionnaire survey based on claims data. J Rheumatol. 2017;44(6):766-72.

25. Andrade FA, Pereira LV, Sousa FA. Pain measurement in the elderly: a review. Rev Latinoam Enferm. 2006;14(2):271-6.

26. World Health Organization. Chronic diseases and health promotion: Chronic rheumatic conditions [Internet]. Geneva: WHO; 2015 [acesso em 05 jan. 2017]. Disponível em: http://www.who.int/chp/ topics/rheumatic/en/

27. Parayba MI, Crespo CD. Diferenciais sociodemográficos na incapacidade funcional dos idosos no Brasil: uma análise das informações do censo demográfico [Internet]. In: $16^{\circ}$ Encontro Nacional de Estudos Populacionais; 29 de set. - 03 de out. 2008; Caxambu. Caxambu : ABEP; 2008 [acesso em 20 nov 2017]. Diponível em: http://www.abep.org.br/ abeporgb/ publicacoes/index.php/anais/article/viewFile/1765/1725

28. Tesch-Römer C, Hans-Werner Wahl. Toward a more comprehensive concept of successful aging: disability and care needs. J Gerontol Ser B Psicol Sci Soc Sci. 2017;72(2):310-8. 